\title{
EFEKTIVITAS PENGGUNAAN MEDIA RODA PUTAR PADA PEMBELAJARAN IPS PESERTA DIDIK KELAS VII SMP ISLAM MANBA'UL ULUM MAYONG JEPARA
}

\author{
Kholis Istifadah, Aisyah Nur Sayidatun Nisa ${ }^{凶}$ \\ Prodi Pendidikan Ilmu Pengetahuan Sosial, Fakultas Ilmu Sosial, Universitas Negeri Semarang, Indonesia
}

\begin{tabular}{l}
\hline Info Artikel \\
\hline Sejarah Artikel: \\
Disubmit: Januari 2021 \\
Direvisi: Februari 2021 \\
Diterima: Maret 2021 \\
\hline Keywords: \\
Program Keluarga \\
Harapan (PKH), \\
Education, School Age \\
Children \\
\hline
\end{tabular}

\begin{abstract}
Abstrak
Pendidikan yang mampu menghasilkan warga negara yang baik ialah pendidikan yang mampu mengembangkan potensi peserta didik, sehingga mampu menghadapi masalah kehidupan yang dihadapinya. Penggunaan sumber belajar dan metode pembelajaran yang kurang variatif dan monoton dapat menimbulkan kejenuhan pada peserta didik karena tidak dilibatkan langsung dalam proses belajar mengajar, akibatnya materi pembelajaran tidak sepenuhnya diterima baik oleh peserta didik, dalam melangsungkan tujuan IPS juga masih terdapat beberapa kendala di sekolah yaitu kurang aktifnya peserta didik dalam menerima pembelajaran IPS, serta belum dimanfaatkannya model atau media secara optimal serta kurangya sarana dan prasarana yang memadai. Permasalahan di atas dapat diatasi dengan diperlukannya kreatifitas guru dalam penggunaan metode, model dan sumber belajar sebagai pendukung proses pembelajaran. Tujuan penelitian ini adalah untuk mengetahui keefektifan pembelajaran IPS menggunakan media roda putar kelas VII F SMP Islam Manba'ul Ulum Jepara.

Abstract

Education that is able to produce good citizens is education that is able to develop student potential, so that they are able to face the life problems they face. The use of learning resources and learning methods that are less varied and monotonous can cause boredom in students because they are not directly involved in the teaching and learning process, as a result the learning material is not fully accepted by students, in carrying out the objectives of social studies there are still some obstacles in school, namely less active students in receiving social studies learning, as well as not optimally utilized models or media and lack of adequate facilities and infrastructure. The problems above can be overcome by the need for teacher creativity in the use of learning methods, models and resources to support the learning process. The purpose of this study was to determine the effectiveness of social studies learning using the class VII F rotating wheel of SMP Islam Manba'ul Ulum Jepara.
\end{abstract}

(C) 2021 Universitas Negeri Semarang

\begin{tabular}{lc}
\hline Alamat korespondensi: & E-ISSN 2685-4929 \\
Gedung C1, Lantai 1, FIS UNNES & \\
Kampus Sekaran, Gunungpati, Semarang, 50229 & \\
Email:aisyah8816@mail.unnes.ac.id. & \\
\hline
\end{tabular}




\section{PENDAHULUAN}

Pendidikan merupakan salah satu hal yang paling penting di dunia ini, dimana dengan Pendidikan semua orang dapat melakukan sesuatu yang besar. Setiap orang, baik disadari atau tidak selalu melaksanakan kegiatan belajar. Kegiatan harian yang dimulai dari bangun tidur sampai dengan tidur kembali akan selalu diwarnai dengan kegiatan belajar. Aktivitas yang dilakukan peserta didik di sekolah tidak semata-mata ditentukan oleh derajat pemilikan potensi peserta didik yang bersangkutan, melainkan juga lingkungan, terutama pendidikan yang professional (Rifa'I,Achmad dkk 2016:67).

Pendidikan merupakan sarana penting untuk meningkatkan kualitas Sumber Daya Manusia (SDM) dalam menjamin keberlangsungan pembangunan bangsa. Peningkatan kualitas SDM jauh lebih mendesak untuk segera direalisasikan terutama dalam mengahadapi era persaingan global. Peningkatan kualitas SDM sejak dini merupakan hal terpenting yang harus dipikirkan secara sunggung-sungguh. Pada dasarnya, pendidikan di Sekolah Menengah Pertama (SMP) mengarahkan supaya peserta didik peka terhadap lingkungan sosial yang terjadi di masyarakat, memiliki sikap mental positif terhadap perbaikan segala ketimpangan yang terjadi dan terampil.

Pendidikan tidak hanya ditekankan untuk mengembangkan pengetahuan saja akan tetapi yang lebih penting adalah peserta didik dapat menerapkan pengetahuan yang diperolehnya dalam kehidupan bermasyarakat. Maka dari itu, diperlukan pendidikan yang bersifat humanis, yang menghormati harkat dan martabat manusia, yang pada dasarnya akan menjadikan atau membentuk peserta didik sebagai pribadi yang utuh dan mampu membangun kerja sama yang kokoh dalam proses kehidupan bermasyarakat dan bernegara, sehingga menjadi warga negara yang baik, mulia, dan keberadaannya dapat membawa dampak kebermanfaatan bagi dirinya maupun lingkungannya.
Peristiwa belajar yang terjadi pada diri peserta didik dapat diamati dari perbedaan prilaku (kinerja) sebelum dan setelah berada dalam peristiwa belajar. Adanya kinerja pada peserta didik itu tidak berarti bahwa peserta didik telah melaksanakan kegiatan belajar, sebab yang dipentingkan dalam makna belajar adalah adanya perubahan perilaku setelah peserta melaksanakan kegiatan belajar.

Undang-Undang Nomor 20 Tahun 2003 tentang Sistem Pendidikan Nasional Bab 1 pasal 3 menyatakan bahwa pendidikan nasional berfungsi untuk mengembangkan kemampuan dan membentuk watak serta peradaban bangsa yang bermartabat dalam rangka mencerdaskan kehidupan bangsa, bertujuan untuk berkembangnya potensi peserta didik agar menjadi manusia yang beriman dan bertaqwa kepada Tuhan Yang Maha Esa, berakhlak mulia, sehat, berilmu, cakap, kreatif, mandiri, dan menjadi warga negara yang demokratis serta bertanggung jawab (Munib, 2015:23).

Undang-Undang No. 20 Tahun 2003 pasal 1 menyebutkan bahwa pendidikan adalah usaha sadar dan terencana untuk mewujudkan suasana belajar dan proses pembelajaran agar peserta didik secara aktif mengembangkan potensi dirinya untuk memiliki kekuatan spritual keagaman, pengendalian diri, kepribadian, kecerdasan, Akhlak mulia, serta keterampilan yang diperlukan dirinya, masyarakat, bangsa dan negara. Berdasarkan Peraturan Menteri Pendidikan Nasional Republik Indonesia Nomor 22 tahun 2006 tentang standar isi untuk satuan pendidikan dasar dan menengah menyebutkan bahwa melalui mata pelajaran Ilmu Pengetahuan Sosial (IPS) peserta didik diarahkan untuk dapat menjadi warga negara Indonesia yang demokratis bertanggung jawab, serta warga dunia yang cinta damai (Permendiknas No.22 Tahun 2006:162).

Pendidikan merupakan suatu yang sangat penting pada era saat ini dan dibutuhkan untuk mendapatkan pekerjaan, karena pada kenyataannya untuk saat ini penerimaan pekerjaan masih di ukur dengan ijazah. Menurut UU nomor 20 tahun 2003 menyatakan bahwa pendidikan adalah usaha 
sadar dan terencana untuk mewujudkan suasana belajar dan proses pembelajaran agar peserta didik secara aktif mengembangkan potensi dirinya untuk memiliki kekuatan spiritual keagamaan, pengendalian diri, kepribadian, kecerdasan, ahlak mulia serta keterampilan yang diperlukan dirinya dan masyarakat, bangsa dan Negara. Sehingga terwujud perubahan pendidikan manusia berkarakter kepribadian bangsa. Pendidikan merupakan faktor penting dalam kehidupan manusia untuk kemajuan suatu bangsa. Undang-Undang Dasar 1945 pasal 31 ayat 1 bahwa setiap warga Negara berhak mendapatkan pendidikan. Maka pendidikan disini berlaku kepada seluruh warga Negara Indonesia tanpa terkecuali.

Mata pelajaran Ilmu Pengetahuan Sosial (IPS) di tingkat sekolah pada dasarnya, bertujuan untuk mempersiapkan para peserta didik sebagai warga negara yang menguasai pengetahuan, keterampilan, siap dan nilai yang dapat digunakan sebagai kemampuan untuk memecahkan masalah pribadi atau masalah sosial serta kemampuan mengambil keputusan dan berpartisipasi dalam berbagai kegiatan kemasyarakatan agar menjadi warga negara yang baik (Sapriya, 2012:12). Mengacu pada pembelajaranIPS,maka diperlukan pembelajaran yang dapat membuat peserta didik yang aktif berpartisipasi dalam pembelajaran IPS dengan menarik minat dan motivasi dalam diri peserta didik sehingga peserta didik mampu memiliki pengetahuan, keterampilan, sikap nilai dan hasil belajar yang baik sesuai dengan tujuan pembelajaran IPS. Artinya, hakikat IPS adalah untuk mengembangkan konsep pemikiran yang berdasarkan realita kondisi sosial yang ada di lingkungan sosial yang ada di lingkungan peserta didik, sehingga dengan memberikan pendidikan IPS diharapkan dapat melahirkan warga negara yang baik dan bertanggung jawab terhadap bangsa dan negaranya.

Faktor-faktor yang memberikan kontribusi terhadap efektivitas belajar adalah kondisi internal dan eksternal peserta didik. Kondisi internal meliputi: kondisi fisik, kondisi psikis, dan kondisi sosial sedangkan kondisi eksternal meliputi variasi dan tingkat kesulitan materi belajar (stimulus), yang dipelajari (direspon), tempat belajar, iklim, suasana lingkungan, dan budaya belajar.

Proses pembelajaran, semua peserta didik menginginkan kenyamanan untuk meningkatkan motivasi belajar di sekolah maupun di rumah, untuk itu sangat penting lingkungan dan suasana yang menyenangkan untuk meningkatkan efektivitas belajar para peserta didik. Tidak hanya dalam hal kenyamanan belajar saja yang dibutuhkan akan tetapi media pembelajaran yang menarik dan kreatif akan menambah minat belajar peserta didik.

Pembelajaran merupakan aspek kegiatan manusia yang kompleks, yang tidak sepenuhnya dapat djelaskan. Pembelajaran merupakan interaksi dua arah dan seorang guru dan peserta didik, di mana antara keduanya terjalin komunikasi (transfer) yang intens dan terarah menuju pada suatu target yang telah ditetapkan sebelumnya (Al-Tabany, 2004:19).

Pada hakikatnya, guru merupakan komponen utama dalam kegiatan pembelajaran. Syaodih dalam Mulyasa (2009:13) menyatakan bahwa guru memegang peranan yang cukup penting baik dalam perencanaan maupun pelaksanaan kurikulum. Tantangan khusus bagi guru di masa kini ialah bagaimana menciptakan pembelajaran yang menggairahkan, menantang nafsu peserta didik dan menyenangkan. Oleh karenaitu,diperlukan guru yang kreatif, professional, dan menyenangkan sehingga mampu menciptakan pembelajaran yang kondusif dan menyenangkan. Dalam menciptakan pembelajaran yang kreatif dan menyenangkandiperlukan berbagai keterampilan mengajar yang baik.

Seiring perkembangan zaman dan kemajuan tekonologi, munculah berbagai media pembelajaran berbasis digital yang lebih menarik perhatian peserta didik. Karena metode ceramah ini cenderung membuat peserta didik menjadi jenuh dan bosan, Tidak adanya inovasi guru dalam menyampaikan materi dapat membuat efektivitas belajar peserta didik tidak tercapai. Berdasarkan hasil observasi di SMP Islam Manba'ul Ulum 
Mayong Jepara, yang hanya memiliki satu orang guru mata pelajaran IPS sulit untuk menyesuaikan dengan penggunaan teknologi masa kini dikarenakan keterbatasan waktu dan tenaga. Serta merupakan sekolah baru yang belum memiliki fasilitas yang memadahi. Proses pembelajaran yang lazim digunakan dalam pembelajaran IPS adalah metode ceramah, dimana guru menyampaikan materi dengan menjelaskan kepada peserta didik. Hasil wawancara dengan beberapa peserta didik SMP Islam Manba'ul Ulum Mayong Jepara, mereka kurang menyukai pelajaran IPS karena IPS dianggap mata pelajaran yang banyak menghafal sehingga peserta didik merasa jenuh, tidak ada inovasi dalam pembelajarannya. Berdasarkan hasil wawancara dengan peserta didik yang bernama Anindia Wilda Sabrina peserta didik kelas VIII D terdapat kendala dalam proses pembelajaran IPS, diantaranya masih kurangnya ketersediaan media pembelajaran, hanya ada satu proyektor yang ada di SMP Islam Manba'ul Ulum dan digunakan untuk semua kelas dan semua mata pelajaran. Dari hasil observasi guru hanya menggunakan metode ceramah dan tanya jawab saja sehingga peserta didik belum bisa memahami materi dengan baik dan antusias peserta didik kurang. Serta dengan adanya penerapan jadwal waktu sekolah yang berbeda dengan sekolah pada umumnya, dimana pada pagi hari khusus untuk peserta didik laki-laki dan siang untuk peserta didik perempuan. Pada jadwal siang hari para peserta didik banyak yang merasa ngantuk dan tidak bersemangat. Dengan hanya menggunakan metode ceramah hal ini membuat tidak tertariknya para peserta didik dalam pelajaran IPS.

Permainan Roda Putar dapat digunakan untuk mengetahui efektivitas belajar mengajar pada pembelajaran IPS peserta didik kelas VII SMP Islam Manba'ul Ulum Mayong Jepara. Maka peneliti akan melakukan penelitian dengan Judul Efektivitas Penggunaan Media Roda Putar Dalam Pembelajaran IPS Peserta didik Kelas VII SMP Islam Manba'ul Ulum Mayong Jepara yang diharapkan efektivitas pembelajaran IPS dapat tercapai dengan baik.

\section{METODE}

Penelitian ini merupakan penelitian PreEkperimental Design atau disebut sebagai eksperimen yang tidak sebenarnya (Semu). Sedangkan desainnya menggunakan One Group Pretest Posttest Design, dipilihnya desain ini dikarenakan untuk mengetahui hasil belajar perserta didik diperlukan data pretest serta posttest yan dilakukan pada satu objek yang sama. Berikut ini beberapa tahapan tahapan yang ditempuh dalam prosedur penelitian dengan menggunakan preeksperimen.

Batasan istilah dalam penelitian ini yaitu dalam penelitian ini peneliti menggunakan indikator evektifitas menurut Sinambela, ada empat indikator efektivitas yaitu: Ketercapaian ketuntasan belajar. Aktivitas belajar peserta didik tinggi. Ketercapaian efektivitas kemampuan guru mengelola pembelajaran. Respon positif terhadap pembelajaran.

Media Pembelajaran pemakaian media pembelajaran dalam proses belajar mengajar dapat membangkitkan minat dan keinginan yang baru, membangkitkan motivasi dan rangsangan kegiatan belajar, dan bahkan membawa pengaruh psikologis. Permainan Roda Putar merupakan sebuah benda yang dimainkan dengan cara diputar.

Mata pelajaran IPS merupakan mata pelajaran yang mengkaji dari berbagai rumpun disiplin ilmu sosial diantaranya Sosiologi, Sejarah, Geografi, dan Ekonomi. Keempat bidang studi ilmu sosial tersebut dipelajari secara terpadu pada jenjang SMP/MTs. Peneliti mengambil mata pelajaran yang ada di kelas VII pada Kompetensi Dasar 3.1 yaitu memahami konsep ruang (lokasi, distribusi, potensi, iklim, bentuk muka bumi, geologis, flora dan fauna) dan interaksi antar ruang di Indonesia serta pengaruhnya terhadap kehidupan manusia dalam aspek ekonomi, sosial, budaya, dan pendidikan. Peniliti mengambil materi pokok kondisi geografis Indonesia (letak dan luas, iklim, geologi, rupa bumi, tata air, tanah, flora dan fauna). 


\section{HASIL DAN PEMBAHASAN}

Penelitian ini dilakukan untuk mencari tahu mengenai keefektifan model yang dipadukan dengan media dalam proses pembelajaran IPS kelas VII di SMP Islam Manba'ul Ulum Mayong Jepara. Pengertian efektifitas secara umum menunjukan sampai seberapa jauh tercapainya suatu tujuan yang terlebih dahulu ditentukan.

Efektivitas dalam pembelajaran tidak hanya mengacu pada proses pembelajaran. Menurut Ellis (Soewandi A.M. Slamet; dkk: 2008:43-44) menambahkan bahwa efektivitas selain mengacu pada proses, juga mengacu pada hasil. Proses dan hasil merupakan sesuatu yang berkesinambungan, dimana proses dilihat dari tercapainya tujuan pembelajaran dan hasil dilihat dari prestasi akademik yang dicapai melalui tes.Indikator efektivitas menurut Mulyasa (2009: 84-85) mengacu pada apa yang ada (input, process, output, dan outcome) kemudian menurut Dengeng (Nai, 2017:317) indikator yang berkaitan dengan pencapaian tujuan pembelajaran yaitu: (1) kesesuaian dengan prosedur; (2) kuantitas unjuk kerja; (3) kualitas hasil akhir. (Nai, 2017: 317). Sementara dalam penelitian ini untuk mengukur tingkat keefektifan peneliti menggunakan 4 sub variabel yaitu keterlaksanaan sesuai dengan rencana pembelajaran, ketercapaian aktivitas belajar dalam kegiatan pembelajaran IPS menggunakan media roda putar yang efektif, meningkatnya hasil belajar peserta didik, respon positif peserta didik terhadap pembelajaran yang telah dilaksanakan. Model pembelajaran merupakan kerangka konseptual atau prosedur untuk melakukan pendekatan dalam pembelajaran yang berisi tentang tujuan - tujuan pembelajaran serta tahap - tahap dalam melakukan proses pembelajaran. Permasalahan dalam menyelesaikan pembelajaran yang berkaitan dengan kualitas pembelajaran tersebut, perlu diterapkan model pembelajaran yang inovatif dan kreatif untuk meningkatkan kualitas pembelajaran IPS pada peserta didik di SMP Islam Manba'ul Ulum Mayong Jepara yaitu dengan menerapkan model pembelajaran Teams Games Tournament (TGT). Model pembelajaran Teams Games Tournament (TGT), dipilih karena model pembelajaran ini adalah salah satu model pembelajaran kooperatif yang mudah diterapkan dan mengandung unsur permainan sehingga memungkinkan peserta didik untuk belajar lebih rileks, menumbuhkan sikap tanggung jawab, serta kerja sama antar teman (Hamdani, 2011:92). memainkan permainan dengan anggota-anggota tim lain untuk memperoleh skor bagi tim mereka masing-masing. Permianan disusun guru dalam bentuk kuis berupa pertanyaan-pertanyaan yang berkaitan dengan materi pelajaran. Kadang-kadang dapat juga diselingi dengan pertanyaan yang berkaitan dengan kelompok (identitas kelompok mereka).

\section{Gambaran Umum SMP Islam Manba'ul Ulum Mayong \\ SMP Pesantren Mamba'ul Ulum} merupakan salah satu lembaga pendidikan di bawah naungan Yayasan Islam Mamba'ul Ulum. terletak di desa Buaran, Mayong, Jepara. Yayasan Islam Mamba'ul Ulum didirikan sejak tahun $1946 \mathrm{M}$ dibawah asuhan KH. Abdul Muhith Al-Magfurillah, dalam bentuk pondok pesantren. Pola pendidikan ponpes Mamba'ul Ulum kala itu masih menggunakan sistem wetonan dan sorogan. Setelah KH. Abdul Muhith wafat, ponpes Mamba'ul Ulum diasuh oleh putra beliau, KH.Fadhil Muhith.Di bawah asuhan KH.Fadhil Muhith sistem pendidikan Mamba'ul Ulum mulai dikembangkan. Dibangunlah madrasah diniyah Mamba'ul Ulum pada tahun 1987 dan taman pendidikan Al-qur'an pada tahun 1990.

Sekarang, perjuangan pengalaman ilmu di Mamba'ul Ulum dilanjutkan oleh KH. M. Amir Wildan dan K.Ustuchuri Fadhil, M.Pd.I, putra KH.Fadhil Muhith Al Magfurillah.pendidikan di Mamba'ul Ulum telah melahirkan lembagalembaga pendidikan baik dalam sistem formal maupun non formal. Salah satunya adalah SMP Pesantren Mamba'ul Ulum. Didirikan pada tahun 2015, SMP Pesantren Mamba'ul Ulum mengusung sebuah pola pendidikan berbasis pesantren. Setiap santri-santriyah SMP Pesantren Mamba'ul Ulum tidak hanya dibekali dengan disiplin ilmu umum akan tetapi juga ilmu keagamaan. 


\section{Kemampuan Guru Dalam Mengelola Pembelajaran}

Data diperoleh dari lembar observasi yang telah diisi oleh guru PPKN kelas VII SMP Islam Manba'ul Ulum Mayong Jepara yaitu Bapak Khoirul Ni'am lembar observasi tersebut mencangkup aspek - aspek yang akan diamati, beliau berperan sebagai observer untuk menilai guru mata pelajaran IPS kelas VII SMP Islam Manba'ul Ulum Mayong Jepara yaitu Bu Nur Amillatus .S, S.Pd pada saat menyampaikan kegiatan pembelajaran didalam kelas yang menggunakan media roda putar.Melalui hasil pengamatan kegiatan pembelajaran IPS menggunakan media roda putar tersebut Pak Ni'am memberikan nilai 76, daftar hasil pengamatan dapat dilihat selengkapnya pada lampiran (belum tau) halaman (belum tau). Pemberian nilai berdasarkan aspek - aspek yang telah disesuaikan dengan instrumen yang telah dibuat oleh peneliti dengan persetujuan dosen pembimbing dan guru mata pelajaran IPS.Kebermanfaatan PKH dalam Menunjang Pendidikan Anak Usia Sekolah.

Berdasarkan kriteria yang didapatkan dapat disimpulkan bahwa pengelolaan guru dalam proses pembelajaran IPS menggunakan media roda putar dikatakan sangat tinggi.

\section{Aktivitas Belajar Peserta Didik}

Aktivitas peserta didik pada saat pembelajaran menggunakan media roda putar dapat dilihat melalui foto serta video. Selain itu, adapun lembar observasi mengenai aspek aspek dalam menilai aktivitas belajar yang dilakukan oleh peserta didik bisa dilihat dalam lampiran 21 halaman 184. Lembar tersebut diisi dan diberikan nilai oleh peneliti dengan cara mengamati aktivitas peserta didik pada saat kegiatan pembelajaran berlangsung.

rata-rata skor aktivitas saat pembelajaran dari ke 32 peserta didik adalah 27,5 dengan standar deviasinya sebesar 1,545 , sehingga termasuk dalam kategori keaktifan yang tinggi saat pembelajaran. Nilai terendah skor aktivitas peserta didik terhadap pembelajaran adalah 25 dan skor tertingginya adalah 30 .

\section{Hasil Belajar Peserta didik}

Data hasil belajar peserta didik diperoleh melalui kegiatan pretest serta posttest. Rekap skor hasil belajar peserta didik yang terdiri dari pretes dan posttes terhadap pembelajaran IPS menggunakan media roda putar pada materi aktivitas manusia dalam memenuhi kebutuhan.

Hasil uji t pada Paired Samples Test menunjukkan nilai sig. < maka ditolak. Sehingga dapat disimpulkan bahwa rata-rata pre-test dan post-test peserta didik pada kelas VII berbeda. Dengan kata lain terdapat peningkatan hasil belajar setelah diberikannya pembelajaran IPS menggunakan media roda putar pada materi aktivitas manusia. Sehingga dapat disimpulkan bahwa pembelajaran IPS media roda putar pada materi aktivitas manusia efektif dalam meningkatkan hasil belajar peserta didik.

\section{Respon Positif Peserta Didik Terhadap Pembelajaran}

Peneliti memberikan angket kepada peserta didik sejumlah 32 orang untuk diisi. Angket tersebut merupakan respon peserta didik terhadap pembelajaran yang telah berlangsung menggunakan media roda putar pada materi aktivitas manusia dalam memenuhi kebutuhan.

Berdasarkan data descriptive statistics dapat diketahui bahwa rata-rata skor respon terhadap pembelajaran IPS menggunakan media roda putar dari ke 32 peserta didik adalah 62,63 dengan standar deviasinya sebesar 3,16 , sehingga termasuk dalam kategori respon tinggi saat pembelajaran, lebih jelasnya ditunjukkan pada tabel 4.16 serta pada gambar 4.6 sebesar $84,38 \%$ siswa merespon tinggi. Nilai terendah skor respon peserta didik terhadap pembelajaran adalah 55 dan skor tertingginya adalah 69.

\section{PEMBAHASAN}

Penelitian ini dilakukan untuk mencari tahu mengenai keefektifan model yang dipadukan dengan media dalam proses pembelajaran IPS kelas VII di SMP Islam Manba'ul Ulum Mayong Jepara. Pengertian efektifitas secara umum menunjukan sampai seberapa jauh tercapainya suatu tujuan yang terlebih dahulu ditentukan.

Efektivitas dalam pembelajaran tidak hanya mengacu pada proses pembelajaran. 
Menurut Ellis ( Soewandi A.M. Slamet; dkk: 2008:43-44) menambahkan bahwa efektivitas selain mengacu pada proses, juga mengacu pada hasil. Proses dan hasil merupakan sesuatu yang berkesinambungan, dimana proses dilihat dari tercapainya tujuan pembelajaran dan hasil dilihat dari prestasi akademik yang dicapai melalui tes.Indikator efektivitas menurut Mulyasa (2009: 84-85) mengacu pada apa yang ada (input, process, output, dan outcome) kemudian menurut Dengeng (Nai, 2017:317) indikator yang berkaitan dengan pencapaian tujuan pembelajaran yaitu: (1) kesesuaian dengan prosedur; (2) kuantitas unjuk kerja; (3) kualitas hasil akhir. (Nai, 2017: 317). Sementara dalam penelitian ini untuk mengukur tingkat keefektifan peneliti menggunakan 4 sub variabel yaitu keterlaksanaan sesuai dengan rencana pembelajaran, ketercapaian aktivitas belajar dalam kegiatan pembelajaran IPS menggunakan media roda putar yang efektif, meningkatnya hasil belajar peserta didik, respon positif peserta didik terhadap pembelajaran yang telah dilaksanakan. Model pembelajaran merupakan kerangka konseptual atau prosedur untuk melakukan pendekatan dalam pembelajaran yang berisi tentang tujuan - tujuan pembelajaran serta tahap - tahap dalam melakukan proses pembelajaran. Permasalahan dalam menyelesaikan pembelajaran yang berkaitan dengan kualitas pembelajaran tersebut, perlu diterapkan model pembelajaran yang inovatif dan kreatif untuk meningkatkan kualitas pembelajaran IPS pada peserta didik di SMP Islam Manba'ul Ulum Mayong Jepara yaitu dengan menerapkan model pembelajaran Teams Games Tournament(TGT). Model pembelajaran Teams Games Tournament (TGT), dipilih karena model pembelajaran ini adalah salah satu model pembelajaran kooperatif yang mudah diterapkan dan mengandung unsur permainan sehingga memungkinkan peserta didik untuk belajar lebih rileks, menumbuhkan sikap tanggung jawab, serta kerja sama antar teman (Hamdani, 2011:92). Menurut Saco (2006), dalam (TGT) peserta didik memainkan permainan dengan anggota-anggota tim lain untuk memperoleh skor bagi tim mereka masing-masing.
Permianan disusun guru dalam bentuk kuis berupa pertanyaan-pertanyaan yang berkaitan dengan materi pelajaran. Kadang-kadang dapat juga diselingi dengan pertanyaan yang berkaitan dengan kelompok (identitas kelompok mereka).

Teams Games Tournament (TGT), memiliki fungsi dan kelebihan dimana peserta didik dapat memainkan permainan dengan anggota-anggota tim lain untuk memperoleh tambahan poin atau skor tim mereka. Salah satu keunggulan dalam Teams Games Tournament (TGT) adalah menggunakan permainan yang dapat disesuaikan dengan topik apapun itu. Artinya, peserta didik dalam proses pembelajaran akan diintegrasikan dengan memainkan game (permainan) akademik. Peserta didik yang berprestasi rendah dan yang berprestasi tinggi mempunyai kesempatan yang sama untuk sukses (Slavin, 1990:6).

Kelebihan pembelajaran kooperatif tipe TGT (Teams Games Tournament) menurut (Taniredja, 2011:72) adalah: Peserta didik memiliki kebebasan untuk berinteraksi dan menggunakan pendapatnya dalam kelas kooperatif. Rasa percaya diri peserta didik menjadi lebih tinggi. Perilaku mengganggu peserta didik lain menjadi lebih kecil. Motivasi belajar peserta didik bertambah. Pemahaman lebih mendalam terhadap pokok bahasan yang dipelajari. Meningkatkan kebaikan budi pekerti, kepekaan, toleransi antara peserta didik dengan peserta didik dan antara peserta didik dengan guru. Peserta didik dapat mempelajari pokok bahasan, bebas mengaktualisasikan diri dengan seluruh potensi yang ada di dalam diri peserta didik dapat keluar, selain itu kerja sama antar peserta didik juga dengan guru akan membuat interaksi belajar di dalam kelas menjadi hidup dan tidak membosankan.

Peserta didik diharapkan memahami materi yang disampaikan oleh guru dengan batuan LKS, buku paket serta keterangan dari guru sebagai sumber pembelajaran. Pada penelitian ini media yang digunakan untuk membantu pembelajaran adalah media roda putar, jadi peserta didik harus mengidentifikasi tentang kelangkaan yang nantinya akan sesuai dan menjadi sumber belajar aktivitas manusia dalam memenuhi kebutuhan. 
Populasi dalam penelitian ini adalah kelas VII. Sementara sampel dalam penelitian ini merupakan kelas VII F, pengambilan sampel dilakukan dengan teknik purposive sampling atau dilakukan dengan melakukan pertimbangan tertentu. Pertimbangan dalam pengambilan sampel ini yaitu ketika peneliti melakukan observasi kondisi peserta didik pada saat belajar yang kurang fokus dalam mengikuti proses pembelajaran, serta kondisi kelas yang ramai pada saat pembelajaran IPS berlangsung sehingga materi yang disampaikan oleh guru tidak sepenuhnya tersamapaikan oleh peserta didik. Materi yang disampaikan saat melakukan penelitian adalah aktivitas manusia dalam menuhi kebutuhan. Pada saat berlangsungnya penelitian, peneliti menyampaikan materi pembelajaran tersebut dengan didampingi oleh guru mata pelajaran IPS pada saat berlangsungnya kegiatan pembelajaran. Berdasarkan hasil penelitian ada 4 sub variabel dalam pembelajaran agar bisa dikatakan pembelajaran efektif.

\section{SIMPULAN}

Berdasarkan hasil penelitian dan pembahasan dapat ditentukan bahwa pembelajaran IPS menggunakan media pembelajaran roda putar dapat dikatakan efektif melalui 2 variabel yaitu Penggunaan media roda putar dalam pembelajaran IPS

Peserta didik mengikuti proses pembelajaran dengan tertib dan menyenangkan walaupun ada peserta didik yang mengganggu peserta didik yang lain karena tidak sabar menunggu giliran kelompok. Semua berjalan dengan lancar sesuai dengan yang diinginkan oleh peneliti. Semua tahap kegiatan dapat terselesaikan dengan baik.

Efektivitas penggunaan media roda putar dalam pembelajaran IPS. Analisis kemampuan guru mata pelajaran IPS kelas VII dalam mengelola pembelajaran mendapatkan nilai 76 dari guru PPKN, dapat disimpulkan dari hasil tersebut bahwa nilai 76 mempunyai kriteria sangat tinggi atau sangat baik sehingga pembelajaran terlaksana sesuai dengan rencana pembelajaran. Aktivitas belajar peserta didik, dari penelitian ini dapat diketahui bahwa aktivitas sebanyak $84 \%$ peserta didik merespon tinggi, sedangkan sisanya $16 \%$ peserta didik merespon sangat tinggi saat pembelajaran berlangsung. Sehingga dapat disimpulkan peserta didik merespon dengan baik saat dilaksanakannya pembelajaran IPS menggunakan media pembelajaran roda putar.

Hasil belajar peserta didik pada penelitian ini diperoleh nilai rata-rata pretest sebesar 56,41 dan nilai rata-rata post test 73,00 , sehingga dapat disimpulkan bahwa hasil akhir pembelajaran IPS menggunakan media pembelajaran roda putar nilai peserta didik mengalami peningkatan yaitu sebesar $60 \%$.

Respon positif peserta didik terhadap pembelajaran dapat diketahui bahwa sebanyak $84 \%$ peserta didik merespon tinggi, sedangkan sisanya $16 \%$ peserta didik merespon sangat tinggi saat pembelajaran berlangsung. Sehingga dapat disimpulkan peserta didik merespon dengan baik saat dilaksanakannya pembelajaran IPS menggunakan media pembelajaran roda putar sehingga dalam sub variabel ini efektif.

Disimpulkan bahwa penggunaan model TGT pada pembelajaran IPS menggunakan media roda putar pada materi aktivitas manusia dalam memenuhi kebutuhan kelas VII F SMP Islam Manba'ul Ulum Mayong Jepara efektif meningkatkan aktivitas belajar mengajar peserta didik.

\section{DAFTAR PUSTAKA}

Mulyasa. 2009. Menjadi Guru Profesional

Menciptakan Pembelajaran Kreatif dan

Menyenangkan. Bandung: PT Remaja Rosdakarya.

Peraturan Menteri Pendidikan Nasional Republik

Indonesia Nomor 22 Tahun 2006 tentang Standar Isi untuk Satuan Pendidikan Dasar dan Menengah. (diunduh 30 April 2020 pukul 21.15 WIB)

Peraturan Pemerintah Republik Indonesia Nomor 19 Tahun 2015 Tentang Standar Nasional Pendidikan. (diunduh pada tanggal 30 April 2020 pukul 21.10 WIB) Riduwan. 2010. 
Kholis Istifadah, dkk / Sosiolium 3 (1) (2021)

Skala Pengukuran Variabel-variabel Penelitian. Bandung: Alfabeta.

Rifa'i, Achmad dan Tri Anni, Catharina. 2015. Psikologi Pendidikan. Semarang: UNNES Press.

Supardi. 2013. Aplikasi Statistika dalam Penelitian Konsep Statistika yang Lebih Komprehensif. Jakarta: Change Publication.

Undang-Undang Nomor 20 Tahun 2003 tentang Sistem Pendidikan Nasional (SISDIKNAS) pasal 1.
Munib, Achmad.2015. Pengantar Ilmu Pendidikan. MKU/MKDK LP3. Universitas Negeri Semarang Press, Cet. 9, 2015.

Sapriya. 2012. Pendidikan IPS Konsep dan Pembelajaran. Bandung: PT Remaja Rosdakarya.

Undang-Undang Nomor 20 Tahun 2003 tentang Sistem Pendidikan Nasional Bab 1 pasal 3 